\title{
Job Enrichment and Work-Related Attitudes of Non-Academic Staff of Selected Public Universities in Lagos State
}

\author{
Rasheed Olawale Azeez \\ Department Of Industrial Relations and Personnel Management \\ Lagos State University, Ojo, Lagos. Nigeria \\ Email: r.azeez2002@gmail.com \\ Motunrayo Mutiat Abimbola \\ Department Of Industrial Relations and Personnel Management \\ Lagos State University, Ojo, Lagos. Nigeria
}

Received: January 26, 2016 Accepted: February 09, 2016 Published: February 27, 2016

doi:10.5296/ijhrs.v6i1.9061 URL: http://dx.doi.org/10.5296/ijhrs.v6i1.9061

\begin{abstract}
This study investigated effects of job enrichment on work-related attitudes in selected public universities in Lagos State. It noted that job enrichment is that type of development in the job environment which may give a worker more challenge, more complete task, more obligation, more prospect for progression, and more effort to contribute his or her ideas for the betterment of the organization. It explores the connection between job enrichment, satisfaction, motivation and performance of employees using the descriptive survey design and utilizing the correlational and regression statistical tools. The study drew its sample from the non-academic staffs of Lagos State University and the University of Lagos which are the public university in Lagos State. The findings revealed that job enrichment is a strong predictor of work-related attitudes (employee satisfaction, motivation, and performance). This study concludes that job enrichment provides skill variety, job identity, feeling important in the eyes of others, responsibility, challenge, realizing ones competence, freedom, participation in decision making, performance feedback from the job done, growth and sense of achievement which leads to internal motivation, satisfaction, and high performance of the non-academic staff.
\end{abstract}

Keywords: Job Enrichment, Performance, Motivation, Satisfaction 


\section{Introduction}

According to Herzberg (1968), job enrichment is that type of advancement in the environment of the job which may give a worker more challenge, more complete task, more responsibility, more prospect for progression, and more chance to contribute his or her ideas to the organization's development. The reason being that unnecessary job specialism introduced by scientific management school of thought and progressing new machinery has been degrading the work by making the workers' job worthless, unchanging, monotonous, eradicating all rigors from it and making the worker a part of the machine culture. As human capabilities and capacity are not being fully used under such conditions, it is a preventive measure which is alienating workers from their jobs.

In this changing world and extremely competitive labour market, organizations need to cope with trends such as rapid product and technology changes, global competition, and demographic changes and to service economy which has increased the need for the organizations to be reactive, springy, modest and inventive. The outdated denotation of an occupation, that is a well-defined set of tasks and activities is destabilized because employees now cannot just limit themselves to their job accounts as they need to adjust to a nonstop varying needs of work (Raza and Nawa 2011; Parvin and Kabir ,2011).

Whilst connecting the workers with functions of managerial ranks is called job enrichment. There is no gainsaying that job enrichment also increases the self-efficacy, self-contentment and self-esteem of the workers which eventually leads to the improved performance of the employees. In a nutshell, job enrichment is a foundation of inspiration for the workers which leads to a goal-oriented performance (Ram and Prabhakar, 2011).

People management, of course, is an important aspect of firm's methods. This evolves from the fact that the human resources of an organization and the organization itself are important because of its mutual interpenetration. A well-organized business organization normally considers the typical workforce as the main cradle of profitability. These business ventures consider staff rather than money as the essential underpinning of the business and sources of a firm's expansion. To ensure the accomplishment of organization's stated objectives, the business must build an atmosphere of obligation and collaboration for its employees through strategies that enables employee contentment. Satisfaction of human resources finds close links to highly motivated employees. These employees then develop sense of involvement or commitment to the firm. This consequently resulted into improved performance and greater productivity in an organization (Parvin and Kabir, 2011). There is no doubt that job enrichment processes have enjoyed enormous popularity both among the theorists and practitioners during the last century. It is to this fact that this study now intends to evaluate the relationship between job enrichment processes and work-related attitudes of non-academic staff in selected public universities in Lagos State. Lagos State is one of the highly urbanized regions of Nigeria with proliferation of higher institutions; there is certainly a need to assess the effects of job design in terms of enrichment on work-related attitudes in terms of job satisfaction, motivation and performance. 


\section{Literature Review}

Job Enrichment - Job enrichment is an approach of adding additional motivators to a job to make it further fulfilling. The concept of job enrichment has its foundation in the motivation-hygiene theory of work attitude (Herzberg, Mausner and Snyderman, 1975; Herzberg, 1968). However, as an job enrichment as an efficient stimulant was propagated by Hackman and Oldham (1976) and was proven by Fredrick Herzberg on the beginning of his studies indicating that the most active way to stimulate workers was by concentrating on greater order necessities. It pursues to add complexity to a job by giving workers more power, more duty, and discretion over how their job is performed as noted by Newstrom (2011) and Kinick and Williams (2009).

Job enrichment means to involve employees in more pleasurable activities. Job enrichment is an effort to inspire employees by giving them enough opportunity to use all their capabilities (Davoudi and Mehdi, 2013). Organizations can enrich employees' job by involving them in decision-making roles of the upper level, giving them more responsibilities, giving them more autonomy, to receive more opinion which enables employees to evaluate their own performance (Neyshabor, 2013). Job enrichment is a work scheme approach for augmenting job content by putting into it more encouraging prospective (Lunenburg 2011). It is an attempt to motivate employees by giving them the opportunity to use their capabilities and capacities as noted in the works of various authors (Pillai, Mashood, Amoodi, Husain and Koshy(2012), Razag and Nawaz, 2011; Mondway, and Noe 1990).

\section{Employee Satisfaction}

Job satisfaction is a state of desire that could be expanded by realizing one's worth to a job (Locke, 1969). Spector (1997) considered job satisfaction as a global feeling about the job, as related constellations of attitudes about various aspects or facets of the job. Salancik and Pfeiffer (1977)affirm that job satisfaction occurs when changing individual needs matches unchanged and precise features of the job. Nonexistence of job satisfaction amounts to negative work place activities such as unproductiveness, workplace abstinence, high turnover and decreased productivity. Employee commitment denotes the level in which an employee attributes him or herself to the occupation and organization and sees its success or failure as his own. (Dost and Khan,2012). Job satisfaction is a set of favorable or unfavorable emotion with which employees understands their job. Job satisfaction is an affecting approach a feeling of relative like or dislike toward something. Satisfaction is the contentment experienced when a want or need is satisfied or a goal is achieved. Job satisfaction according to Mullins (2010) is a complex and many-sided construct which different people can see it from different perspective and that job satisfaction is more of an attitude, an internal state. An employee that does not have a job satisfaction will apparently have no quality of work-life (Azeez, 2015).

\section{Employee Motivation}

Due to promptly changing business environment, organizations in the world wants to use the maximum potential, capacities and capabilities of their employees to the fullest and to gain a 
ground in the battle-like expedition. Excellent establishments are erected on the essential worth of their human resources as inspired and loyal employees continually allows a business to grow faster than comparable competitive firms.

Employee motivation is a generally cherished program presently across all corporate sectors regardless of their size. Today, organizations from all around the world struggle to encourage its personnel in order to last and contest in the vigorous business atmosphere magnificently. The workers action advances great level of efficacy of workers, enables the organizations to attain sustainable viable advantage over the competitors and finally leads to the achievement of organizational goals.

\section{Employee Performance}

In a capitalist economy as Nigeria's, it is difficult to adopt a job design practice to enhance employee performance. Invariably, enriched or enlarged job design alone cannot enhance employee performance. Therefore, organizations are usually influenced by the criteria of applying the most suitable job design characteristics (Okoh, 2005). At one extreme, marginal organizations enhance enlarged job designs in an attempt to create room for profit maximization. At the other extreme, some organizations adopt enriched job designs to enhance favorable work environment and to bring about improved organizational productivity. However, the concept of employee performance is most often dependent on the reward practices within the organizational system. Consequently, organizations are influenced by the criteria of ability to pay a prevailing reward structure in the industry (Okoh, 2005). At one end, some organizations pay the minimum wage fixed by government or what would enable them attract and retain the required number and type of labour. At the other end, some organizations pay well above the prevailing rate in the labour market because they want to attract and retain the very best and highest caliber of labour force obtainable. By paying higher rates, management is able to demand superior performance from its employees. The slogan 'pay good wage, attract superior workers' who can produce average and raise the profit margin of the organization is applicable here, such managers believe in the survival of the fittest as well as the economy of high wages to enhance optimal performance of the employees in an organization.

A sound reward practice is to base all wage practices on proper rates of evaluation of jobs in the organization. Job evaluation, according to Eze (2004), helps to establish fair reward differentials, internal consistency of wage rates, based on different job contents, for improved employee performance. For external consistency, it can achieve that by periodic wage survey of the labour market within its operational environment and industry.

\section{Job Enrichment and Employee Motivation}

In Lunengburg(2011), investigation on stimulating employees by enriching jobs to make them interesting and challenging. It was noted job enrichment leads to higher job satisfaction and motivation. Employees performing enriched jobs usually experience lower absenteeism and turnover and high performance. And enriching certain elements of job alters people's psychological states in a way that develops their work success. Locke(1968) conducted 
research on a theory of task motivation and incentives and also in organizational behavior and human performance. The study observed that there is a positive relationship between participation and the completion of goals by the workers when their jobs are enriched. And that job enrichment also increase the motivation level and performance of employees in the work place and their tendency to achieve the goals also becomes more possible.

Fourman and Jones (1997) in their study found out that job enrichment influences motivation of employees who are in the middle of their career. Key factors described in job enrichment are hygiene and motivational factors. Their study aims to prove that apart from this vertical job enrichment adds more power, responsibility and knowledge to job thereby increasing motivational factors such as accountability, accomplishment, development and knowledge on the same job, therefore it leads to positive motivation and job satisfaction for the employee.

\section{Job enrichment and Employee Performance}

However, Pierce and Dunham (1976) in their research found out that the relationship between job enrichment and performance is not too strong, also that emotional and motivational responses are more strongly related to task design than are the behavioural responses. Their finding also reveal that job enrichment often results in higher quality, less turnover, and absenteeism, fewer grievances, and a generally more commitment workforce.

Saleem,Shaheen and Saleem (2012) researched the impact of job enrichment and job enlargement on employee satisfaction keeping employee performance as intervening variable, in their study in Pakistan. Data were collected from 250 people from public and private organizations from Lahore, Rawalpindi and Islamabad Region in Pakistan. The analysis of variance (ANOVA) results show that (i) job enrichment and job enlargement have a positive relationship with the level of employee satisfaction; and (ii) Job performance as moderator influences the relationship between job enrichment and job enlargement and employee satisfaction. The study found that enriched and enlarged job enhanced the performance of employees in the organization.

This present study, therefore, intends to access the moderating effect of growth-need strength on the relationship between job enrichment and work-related attitudes in selected public universities in Lagos State.

\section{Statement of Hypotheses}

$\mathrm{H}_{1}$ : Job enrichment does not have a significant relationship with employee satisfaction.

$\mathrm{H}_{2}$ : Job enrichment does not have a significant relationship with employee motivation.

$\mathrm{H}_{3}$ : Job enrichment does not have a significant relationship with employee performance.

\section{Methodology}

The research design for this study is the descriptive survey. The data for this study was collected through questionnaires from two public university located in Lagos, Southwest Nigeria. Quota and simple random sampling techniques were adopted; one hundred and seventy six (176) questionnaires each were administered in each university totaling three 


\section{Macrothink

hundred and fifty two (352) questionnaires.

The instrument Reliability test was conducted to ascertain whether the developed factors measured consistently the factors intended to measure. The result of the pilot study indicates a high level of internal consistency among four (4) constructs: job enrichment (0.79), employee satisfaction (0.84), employee performance (0.81), and employee motivation (0.74). Seventeen $(4.8 \%)$ of the returned questionnaires was excluded in the analysis because of its unusable status. Therefore, only three hundred and thirty five (335) comprising of 109 $(32.5 \%)$ females and $226(67.5 \%)$ males were included in the analysis.

In addition, parametric statistical tool for correlational and regression analyses was used in testing the hypotheses as well as in determining the degree of relationships among the variables. Simple regression is relevant in a situation when researcher has to establish a relationship between dependent and independent variables.

The simple regression models for this study are given below:

$\mathrm{Y}=\mathrm{f}(\mathrm{X})$,

$\mathrm{X}=\mathrm{x}_{1}$

Where: $\mathrm{X}_{1}=\mathrm{Job}$ enrichment

$\mathrm{Y}=\beta_{\mathrm{o}}+\beta_{1 \mathrm{it}} \mathrm{x}_{1}+\varepsilon_{\text {it }}$

Where: $\varepsilon=$ Error term

While

$\mathrm{Y}=\mathrm{y}_{1}, \mathrm{y}_{2}, \mathrm{y}_{3}$

Where:

$\mathrm{y}_{1}=$ Employee satisfaction

$\mathrm{y}_{2}=$ Employee motivation

$\mathrm{y}_{3}=$ Employee performance 


\section{Mll Macrothink}

\section{Results and Discussion}

\section{Correlation Analysis}

\section{Correlation Matrix}

\begin{tabular}{|c|c|c|c|c|}
\hline & $\begin{array}{l}\text { Job } \\
\text { Enrichmen } \\
\mathrm{t}\end{array}$ & $\begin{array}{l}\text { Employee } \\
\text { Satisfactio } \\
\mathrm{n}\end{array}$ & $\begin{array}{l}\text { Employee } \\
\text { Motivatio } \\
\mathrm{n}\end{array}$ & $\begin{array}{l}\text { Employee } \\
\text { Performan } \\
\text { ce }\end{array}$ \\
\hline $\begin{array}{ll}\text { Job } & \text { Pearson Correlation } \\
\text { Enrichm } & \\
\text { ent } & \text { Sig. (2-tailed) }\end{array}$ & 1 & $\begin{array}{l}.663 \\
.000\end{array}$ & $\begin{array}{l}.664 \\
.000\end{array}$ & $\begin{array}{l}.603 \\
.000\end{array}$ \\
\hline $\begin{array}{l}\text { Employe Pearson Correlation } \\
\text { e } \\
\text { Satisfact Sig. (2-tailed) } \\
\text { ion }\end{array}$ & $\begin{array}{l}.663 \\
.000\end{array}$ & 1 & $\begin{array}{l}.360 \\
.000\end{array}$ & $\begin{array}{l}.236 \\
.000\end{array}$ \\
\hline $\begin{array}{l}\text { Employe Pearson Correlation } \\
\text { e } \\
\text { Motivati Sig. (2-tailed) } \\
\text { on }\end{array}$ & $\begin{array}{l}.614 \\
.000\end{array}$ & $\begin{array}{l}.360 \\
.000\end{array}$ & 1 & $\begin{array}{l}.308 \\
.000\end{array}$ \\
\hline $\begin{array}{l}\text { Employe Pearson Correlation } \\
\text { e } \\
\text { Perform Sig. (2-tailed) } \\
\text { ance }\end{array}$ & $\begin{array}{l}.603 \\
.000\end{array}$ & $\begin{array}{l}.236 \\
.000\end{array}$ & $\begin{array}{l}.308 \\
.000\end{array}$ & 1 \\
\hline
\end{tabular}

The result of the Pearson's Product Moment Correlation matrix above examines the relationship between the dependent variables and the predictor variable. The result reveals that the predictor variable (job enrichment) had a strong positive relationship with the dependent variable work-related attitudes in different magnitudes given their correlation coefficient to be (employee satisfaction $r=0.663$, employee motivation $r=0.614$, and employee performance $r=0.603$ respectively. Similarly, all the results were statistically significant at the 0.05 alpha levels, given all their associated $p$-values to be less than $0.05(\mathrm{p}<0.05)$. 


\section{Model Testing}

Model one: $\mathrm{y}_{1+} \mathrm{y}_{2}+\mathrm{y}_{3}=\mathrm{f}\left(\mathrm{x}_{1}\right)$ (Job Enrichment)

Model Summary

\begin{tabular}{|l|l|l|l|l|}
\hline Model & $\mathrm{R}$ & R Square & Adjusted R Square & $\begin{array}{l}\text { Std.Error of the } \\
\text { Estimate }\end{array}$ \\
\hline 1 & $.527^{\mathrm{a}}$ & .278 & .271 & .769 \\
\hline
\end{tabular}

Predictors: (Constant), job enrichment

Dependent Variable: Work related attitudes

\section{Coefficients of Standard error and beta}

\begin{tabular}{|c|c|c|c|c|c|}
\hline \multirow[b]{2}{*}{ Model } & \multicolumn{2}{|c|}{$\begin{array}{l}\text { Un-standardized } \\
\text { Coefficients }\end{array}$} & \multirow{2}{*}{\begin{tabular}{|l} 
Standardized \\
Coefficients
\end{tabular}} & \multirow[b]{2}{*}{$\mathrm{T}$} & \multirow[b]{2}{*}{ Sig. } \\
\hline & $\mathrm{B}$ & Std. Error & & & \\
\hline $1 \quad$ (Constant) & 1.640 & .255 & & 6.425 & .000 \\
\hline Employee satisfaction & .134 & .039 & .143 & 3.415 & .001 \\
\hline Employee motivation & .121 & .039 & .133 & 3.092 & .002 \\
\hline Employee performance & .137 & .040 & .135 & 3.405 & .001 \\
\hline
\end{tabular}

a. Dependent Variable: Work related attitudes

\section{Interpretation}

The table above shows the output of the multivariate regression analysis used in testing the first model. The result shows that job enrichment was statistically significant in predicting all the dependent variables (Employee satisfaction, Employee motivation, and Employee performance). In other word, given all the associated significant p-values to be less than 0.05 for each of the dependent variables (Employee satisfaction $=0.000$, Employee motivation $=$ 0.001, and Employee performance $=0.000)$. The coefficient of determination $\left(\mathrm{R}^{2}=0.278\right)$ 
indicates that the predictor variable (job enrichment) is accounting for $28 \%$ variation on the dependent variable. The remaining difference $(72 \%)$ in the variance might be due to the influence of other factors not considered in this study.

We can simply conclude that job enrichment had significant impact on the work related variables. Likewise, the test of the overall model was found to be statistically significant, given $\mathrm{F}$ - value of 41.382 and $\mathrm{p}=0.000$.

\section{Test of Hypotheses}

$\mathbf{H}_{1}$ : Job enrichment does not have a significant relationship with employee satisfaction of non-academic staff in selected public universities in Lagos State.

Correlation (Pearson Product Moment Correlation (PPMC) of job enrichment and satisfaction

\begin{tabular}{|l|l|l|l|l|l|l|}
\hline Variables & $\mathrm{N}$ & Mean & Std. Deviation & $\mathrm{R}$ & $\mathrm{P}$ & Remark \\
\cline { 1 - 6 } Job Enrichment & 352 & 4.94 & 0.65 & 0.663 & .000 & Significant \\
\cline { 1 - 5 } Employee Satisfaction & 352 & 4.81 & 0.73 & & & \\
\hline
\end{tabular}

\section{Interpretation}

From the research hypothesis tested above using Pearson Product Moment Correlation (PPMC), it was observed that there is a significant positive relationship between job enrichment and employee satisfaction $(\mathrm{R}=0.663, \mathrm{p}<0.05)$. Hence, the null hypothesis $\left(\mathrm{Ho}_{1}\right)$ which states that Job enrichment does not have a significant relationship with employee satisfaction in selected public universities in Lagos State is hereby rejected.

Summary showing Linear Regression/Analysis of Variance on the effect of Job enrichment on employee satisfaction of non-academic staff in selected public universities in Lagos State.

ANOVA

\begin{tabular}{|l|l|l|l|l|l|}
\hline & Sum of Squares & Df & Mean Square & F & Sig. \\
\hline Regression & 126.988 & 1 & 126.988 & 428.224 & $.000^{\mathrm{b}}$ \\
\hline Residual & 161.617 & 334 & .297 & & \\
\hline Total & 288.605 & 335 & & & \\
\hline $\begin{array}{l}\mathrm{R}=0.663 \\
\mathrm{R} \text { Square }=0.440\end{array}$ &
\end{tabular}




\section{Macrothink}

\section{Interpretation}

The table above shows that job enrichment significantly influence employee satisfaction $\left(\mathrm{F}_{1,334}=428.224, \mathrm{p}<0.05\right)$. Further evidenced is the fact that the percentage of variance in employee satisfaction explained by job enrichment is about $44 \%$.

\section{Discussion}

This empirical study was conducted in partial determination of the effect of job enrichment on employee satisfaction of non-academic staff in selected public universities in Lagos State, while statistical test were applied to test the hypothesis. In the light of the statistical results in which at a significant level of 0.05 , it transpired that job enrichment has significant effect on employee satisfaction in the two public universities surveyed. The findings of this study are supported by definition of Job enrichment according to Hackman \& Oldham (1976) and Raza and Nawaz (2011). However, from the finding of this study and the empirical evidences from other studies from the literatures, job enrichment has effect on the satisfaction of employee in the selected universities survey.

\section{Hypothesis Two}

$\mathbf{H}_{2}$ : Job enrichment does not have a significant relationship with employee motivation of non-academic staff in selected public universities in Lagos State.

\section{Correlation (Pearson Product Moment Correlation (PPMC) of job enrichment and employee motivation}

\begin{tabular}{|l|l|l|l|l|l|l|}
\hline Variables & $\mathrm{N}$ & Mean & Std. Deviation & $\mathrm{R}$ & $\mathrm{P}$. & Remark \\
\hline Job Enrichment & 335 & 4.94 & 0.65 & 0.664 & .000 & Significant \\
\cline { 1 - 4 } & 335 & 4.82 & 0.74 & & & \\
\hline
\end{tabular}

\section{Interpretation}

The Pearson Product Moment Correlation (PPMC) was used to test the above hypothesis which states that "Job enrichment does not have a significant relationship with employee motivation of non-academic staff in selected public universities in Lagos State". Table above showed that there is a strong positive relationship between the independent and dependent variables, which are job enrichment and employee motivation $(\mathrm{r}=0.664, \mathrm{p}<0.05)$. Hence the null hypothesis which states that "Job enrichment does not have a significant relationship with employee motivation of non-academic staff in selected public universities in Lagos State" is rejected. 


\section{MInstitute ${ }_{\text {Mach }}^{\text {Macrothink }}$}

Summary showing Linear Regression/Analysis of Variance on the effect of Job enrichment on motivation in selected public universities in Lagos State.

ANOVA

\begin{tabular}{|l|l|l|l|l|l|}
\hline Model & $\begin{array}{l}\text { Sum } \\
\text { Squares }\end{array}$ & Df & Mean Square & F & Sig. \\
\hline Regression & 130.599 & 1 & 130.599 & 430.035 & $.000^{\mathrm{b}}$ \\
\hline Residual & 165.513 & 334 & .304 & & \\
\hline $\begin{array}{l}\text { Total } \\
\text { R }=0.663 \\
\text { R Square }=0.441\end{array}$ & 335 & & & \\
\hline
\end{tabular}

a. Dependent Variable: Employee Motivation

b. Predictors: (Constant), Job Enrichment

\section{Interpretation}

Further evidence from table 4.18 showed that job enrichment significantly influences employee motivation $\left(\mathrm{F}_{1,334}=430.035, \mathrm{p}<0.05\right)$. Also evidenced is the fact that the percentage of variance in employee motivation explained by job enrichment is about $44.1 \%$.which showed the extent of the effect of job enrichment on employee motivation and also answer the question To what extent is the relationship between job enrichment and employee motivation of non-academic staff in selected public universities in Lagos State?

\section{Discussion}

The second hypothesis was to ascertain whether job enrichment has any significant effect on employee motivation in the selected public universities in Lagos State. However the findings revealed that job enrichment has statistical strong positive relationship with employee motivation among the non-academic staff in the two selected public universities used for this study. This is inconsonance with the findings of Odiorne, (1970), that job enrichment is a source of motivation for the employees and it leads to a goal-oriented behaviour. By increasing the scope of the employee's work, one also increases their motivation level, the performance of the employees at the work place and their propensity to achieve the goals (Ronan, Latham and Kinne, 1973; Myers, 1970). However, from the finding of this study and the empirical evidences from other studies from the literatures, job enrichment has effect on the motivation of employee in the selected universities under survey. 


\section{Macrothink}

\section{Hypothesis Three}

$\mathbf{H}_{3}$ : Job enrichment does not have a significant relationship with employee performance of non-academic staff in selected public universities in Lagos State.

Pearson Product Moment Correlation (PPMC) of job enrichment and employee performance.

\begin{tabular}{|l|l|l|l|l|l|l|}
\hline Variables & $\mathrm{N}$ & Mean & Std. Deviation & $\mathrm{R}$ & $\mathrm{P}$ & Remark \\
\hline Job Enrichment & 335 & 4.94 & 0.65 & 0.603 & .000 & Significant \\
\cline { 1 - 4 } Employee Performance & 335 & 4.93 & 0.68 & & & \\
\hline
\end{tabular}

\section{Interpretation}

From the research hypothesis tested above using Pearson Product Moment Correlation (PPMC), it was observed that there is a significant positive relationship between job enrichment and employee performance $(\mathrm{R}=0.603, \mathrm{p}<0.05)$ the null hypothesis and conclude that Job enrichment had significant relationship with Employee performance in selected public universities in Lagos State is rejected.

Summary showing Linear Regression/Analysis of Variance on the effect of Job enrichment on employee performance in selected public universities in Lagos State.

ANOVA

\begin{tabular}{|c|c|c|c|c|c|}
\hline & $\begin{array}{l}\text { Sum of } \\
\text { Squares }\end{array}$ & Df & Mean Square & $\mathrm{F}$ & Sig. \\
\hline Regression & 91.969 & 1 & 91.969 & 310.772 & $.000^{\mathrm{b}}$ \\
\hline Residual & 161.285 & 334 & .296 & & \\
\hline Total & 253.254 & 335 & & & \\
\hline \multicolumn{6}{|l|}{$R=0.60$} \\
\hline \multicolumn{6}{|c|}{ R Square $=0.363$} \\
\hline
\end{tabular}

\section{Interpretation}

Further evidenced from the table above showed that the percentage of variance in employee motivation explained by job enrichment is about 36.3\%.which answer the research question that To what extent is the relationship between job enrichment and employee performance of non-academic staff in selected public universities in Lagos State? 


\section{Discussion}

The findings of the study revealed that the predictor variable (job enrichment) had a strong positive relationship with employee performance $r=0.60$. This empirical study was conducted in partial determination of the effect of job enrichment on employee performance of non-academic staff in selected public universities in Lagos State, while statistical test were applied to test the hypothesis. In the light of the statistical results in which at a significant level of 0.05 , it become apparent that job enrichment has significant effect on employee performance in the two public universities in this surveyed. The finding of this study is in consonance with the findings of Lunengburg (2011) investigation on stimulating employees by enriching jobs to make them interesting and challenging. Job enrichment also increases the self-efficacy, self-mechanization and self-respect of the workers. This leads to the triumph of the workers in successful performance (Vroom 1964; Swinth, 1971).

\section{Conclusion and Recommendation}

The findings showed that job enrichment is a strong predictor of work-related attitudes (employee satisfaction, motivation, and performance). The finding revealed that job enrichment provides skill variety, job identity, feeling important in the eyes of others, responsibility, challenge, realizing ones competence, freedom, participation in decision making, performance feedback from the job done, growth and sense of achievement which led to internal motivation, satisfaction, and high performance of the non-academic staff.

Also the findings of this study revealed that there is positive relationship between the independent variable (job enrichment) and the dependent variables (work-related attitudes). It is therefore concluded that job enrichment is being practice in the two selected public universities in Lagos State. And that job enrichment has significant effect on the work-related of non-academic staff in the selected public universities in Lagos State. The study has provided empirical evidence to support theoretical model that prescribe a link between job enrichment and work-related attitudes (employee satisfaction, employee motivation, and employee performance).

It is recommended that since it was apparent from the review of existing literature and empirical results of this study that job enrichment is a vital instrument for organizations to equip their employees in today's dynamic world and highly competitive labour market, therefore human resource managers of these selected public universities should ensure that job enrichment design is properly implemented.

The human resource management should understand/ caution that job enrichment may not be applicable to all employees in the organization, that it has a motivational influence for employees that desire challenge in doing demanding jobs, have the abilities to perform, and are motivated to satisfy higher order needs, enjoy work itself, autonomy and feedback from performance and may have negative effect on worker that have low motivational influence.

Human resource managers of the selected public universities surveyed should take account of individual differences, attributes and people orientation to work. From the findings it was cleared that employees are motivated by different things, management should not generalize 
the motivation strategies, rather individual should be motivated accordingly, as what will motivate employee A may not motivate employee B.

Also what will satisfy employee A may not satisfy employee $B$, therefore management should observe and know what satisfy each employee .The human resource manager should encourage the employees with high growth-need strength and find strategies for helping those with low growth- need strength through training. The management of selected public universities in Lagos State can increase the levels of employee satisfaction of their non-academic personnel by making sure that working conditions conform to standardized workplace designs. Unpleasant working conditions result in employee dissatisfaction.

To increase the other work-related factors, management of theselected public universities in Lagos State should put in place policies that would facilitate work-related factors in their institutions. Example of such policies include compensation policy and human capital development policies.

\section{References}

Azeez, R.O. (2015) The influence of employees' Job Satisfaction and Turnover intention on Organizational Commitment: A Case-study of Lagos State University. Unpublished M.Sc dissertation.Department of IRPM, Lagos State University.

Davoudi, M., \& Mehdi, S. (2013).Impact of job enrichment in organizational citizenship behavior.SCMS Journal of Indian Management, 10(2), 106-112.

Dost, M.K.B. \& Khan H.J. (2012). Job enrichment causes high level of employee commitment during the performance of their duties: Behavioural Study. Arabian Journal of Business Management Review (OMAN Chapter) 1(9), 95-104.

Eze, N. (2004).Industrial-Organizational Psychology. Lagos: Pumark Press Ltd.

Fourman, L. S., \& Jones, J. (1997) Job enrichment in extension.http:// www.joe.org/joe//iw1.php, Accessed on 18th December, 2015.

Gruenberg, M. M. (1979). Understanding job satisfaction. London: The Macmillan Press Ltd Hackman, J.R.,\& Oldham, G.R. (1976) Motivating through the design of work: Test of a theory. Organizational Behaviour and Performance, 16: 250 - 279.

Herzberg, F. (1968) One more time: How do you motivate employees? Harvard Business Review, 46, 53-62.

Herzberg, F., Mausner, B., \&Snyderman, B. (1975) The motivation to work (12 ${ }^{\text {th }}$ Ed.) New Brunswick: Transaction Publishers.

Kinicki, A. \& Williams B.K. (2009) Management: A practical Introduction $\left(4^{\text {th }}\right.$ Ed.). Boston: McGraw- Hill Irwin.

Locke E.A. (1968) Towards a theory of task motivation and incentives. Organizational 
Behaviour and Human Performance, 3(1), 157-189. 2016, Vol. 6, No. 1

Locke, E. A. (1969). What is job satisfaction? OrganisationalBehaviour and Human Performance, 4(1), 309-336.

Lunenburg,F. C.(2011).Expectancy Theory of Motivation: Motivating by Altering Expectations.International Journal of Management, Business and Administration.

Mondway, R.W. \&Noe, R.M. (1990).Human Resource Management (4 ${ }^{\text {th }}$ Ed).Washington DC: Allyn and Bacon.

Mullins, L. J. (2010) Management and OrganisationalBehaviour ( $9^{\text {th }}$ Ed.). New York: Pearson.

Myers, M. S. (1970). Every employee: A Manager. New York: McGraw-Hill.

Newstrom, J. W. (2011) Organisationalbehaviour: Human behavior at work (13 ${ }^{\text {th }}$ Ed.). New York: McGraw-Hill.

Neyshabor, R. (2013). An Investigation of the Relationship between Job enrichment and Organizational Commitment International Journal of Research in Organizational Behavior http://www.aijsh.org/setup/international/paper12.pdf

Odiorne, G. S. (1970). Management-by-objectives. New York: Pitman.

Okoh, A.O. (2005). Personnel and Human Resource Management in Nigeria ( $2^{\text {nd }}$ Ed.). Lagos: Amfitop Books Ltd.

Parvin, M. M. \&Kabir, N. (2011) Factors affecting employee job satisfaction of pharmaceutical sector. Australian Journal of Business and Management Research, 1(9), 113-123.

Pierce, J. L., \& Dunham, R.B.(1976) Task design: A literature review. Academy of Management Review, 1(1), 83-97.

Pillai,K.R., Mashood,A., Amoodi,S.S, Husain,K, \&Koshy, R.I. (2012). Factors underlying Job Enrichment among Expatriate Employees: A regional perspective. Accessed on $20^{\text {th }}$ December 2015 at www.highbeam.com/doc/IGI-315222381.html.

Ram, P. \&Prabhakar, G. V. (2011) The role of employee engagement in work-related outcomes. Interdisciplinary Journal of Research in Business; 1(3), 47-61.

Raza, M.A. \& Nawaz, M.M. (2011) Impact of job enrichment on employee's job satisfaction, motivation and organizational commitment: Evidence from public sector of Pakistan. International Journal of Business and Social Science 23 (2), 220-226.

Ronan, W.W., Latham, G.P., \&Kinne, S.B. (1973) The effects of goal setting and Supervision on worker behaviour in an industrial situation. Journal of Applied Psychology,57(1), 302-307.

Salancik, G. R., \&Pfeffer, J. (1977) An examination of need-satisfaction models of job 


\section{Macrothink \\ International Journal of Human Resource Studies \\ ISSN 2162-3058 2016, Vol. 6, No. 1}

attitudes. Administrative Science Quarterly, 22(1), 224-456.

Saleem, S., Shaheen, W.A. \&Saleem, R. (2012) The impact of job enrichment and job enlargement on employee satisfaction, keeping employee performance as intervening variable: A correlational study from Pakistan. Arabian Journal of Business and Management Review 1, (9), 145-165.

Spector, P.E. (1997). Job satisfaction: Application, assessment, cause, and consequences. California: Sage Publications, Inc.

Swinth, R. L. (1971). Organizational joint problem-solving; Management Science, 18, B68-B79.

Vroom, V. H. (1964). Work and Motivation. New York: Wiley. 